Arutyun W. Amalian, Ph.D. in Economics, Assistant Professor, Ukrainian-American Concordia University (Kyiv, Ukraine)

Nataly D. Amalyan, Ph.D. in Economics, Assistant Professor, Ukrainian-American Concordia University (Kyiv, Ukraine)

\title{
MODERN TRENDS IN GDP-LINKED SECURITIES DESIGN
}

Abstract. Numerous research papers substantiate the idea that GDP-linked bonds could provide a potential means for indebted countries to avoid default (the cost of which to be measured by an endowment loss and temporary exclusion from capital markets) by linking current reduction of the total outstanding debt with liabilities to share future gains of growth of national economy. Actualization of this idea has already taken place in a dozen of countries. This article presents comparative analysis of background, terms and condition of the last three cases of GDP-indexed bonds emission - by Argentina, Greece and Ukraine. Commensuration of the share of haircut, threshold for payments and availability of the cap provides for detection of trends in the design of these debt instruments.

Keywords: GDP-linked bonds, warrants, moral hazard, debt restructuring, cap, hair-cut

GDP-linked bonds are considered to be a product of modern financial engineering. But over the past centuries financial instruments of similar nature were known and widely used in practice: in 1782 the State of Virginia, for example, has issued bonds linked to the price of land and slaves and in 1863 the Confederate States of America has issued 'cotton' bonds, either payable in pounds or francs or convertible into cotton at a predetermined price. But the theoretical substantiation such practice of indexed securities issuance received only at the end of XX century.

\section{Literature review}

Since the early 1980s in the aftermath of Less Developed Countries Debt Crisis many economists have been holding debate on a question of the treatment of countries nearing default, the options being forced conditionality agreements or "forgiveness, indexation, and investment incentives" (Froot at al, 1989).

Emergence of the new concept (conditional fractional debt forgiveness) was stipulated by the change of common attitude to financial crises: from the statement that crises occur 
once in a while, acting as helpful disciplining devices on irresponsible governments to understanding that crises are exceedingly costly and impose major negative externalities not only on the borrowing countries, but also beyond their borders on international financial markets and other borrowing countries (Borensztein and Paolo, 2004). As stated by Jeffrey Sachs, partial debt forgiveness could actually raise the expected repayments to the creditors, while at the same time giving greater incentive to the country for favorable adjustment (Sachs, 1988).

IMF experts have developed new techniques for converting external debt into equity or local currency claims, which together with other forms of debt conversion accounted for $\$ 2,1-2,4$ billion decrease in external claims of commercial banks on developing countries in 1986 (Annual Report, 1986, p.168). In the 1980s Costa Rica, Bulgaria, and Bosnia and Herzegovina, as part of Brady restructuring agreements, have issued bonds with certain elements of indexation to their national GDP (or GDP per capita). These bonds contained clauses enabling the payoff to bondholders if the chosen parameter of the debtor country rises above a certain level. Later on this practice was used while restructuring sovereign bonds of Argentina, Greece and Ukraine. Comprehensive analysis of the emission of indexed securities in the XX - first decade of XXI century is provided by John Williamson (Williamson, 2017), Eduardo Borensztein and Paolo Mauro (Borensztein and Mauro, 2002), Experts of the UN Department of Economic and Social Affairs Stephany Griffith-Jones and Krishnan Sharma (Griffith-Jones and Sharma, 2006) and others. Extreme case of the importance attached to GDP-linked securities is manifested by the title of the paper "Warrant Economics", where the term 'warrant' is used to denote options (i.e. rights) on a sovereign's current and, most importantly, future wealth, implicitly issued by the state itself (Hatgioannide and Karanassou, 2011).

At present new line of research is connected with the analysis of the suitability of the primary emission of GDP-linked securities (contrary to their emission while restructuring old debts). The idea of the original growth-linked securities emission is advocated by such distinguished economists, as Nobel-prize winner Robert Shiller, Jonathan D. Ostry, James Benford (Sovereign, 2018), Paul Krugman, John Williamson, Joseph Stiglitz and many others. But, unfortunately, their works do not include in-depth analysis of the latest emission of GDP-linked warrants by Ukraine.

The main objective of this paper is to provide a comparative analysis of background, terms and condition of GDP-indexed bonds emission by Argentina, Greece and Ukraine and to trace the trends in the design of these financial instruments. 


\section{Research results}

In 1988 Paul Krugman (Krugman, 1988) considered the relative merits of converting debt to proportional claims on exports (suggestion of Norman Bailey) compared to indexing debt to some general measure of ability to repay (for example making debt repayment proportional to export revenues) or to linking repayment to some measure of the shocks experienced by a country, such as the level of world interest rates or the price of the country's principal export goods. Any choice, as Paul Krugman emphasized, implies that "the obligation is simply rescheduled, at market interest rates, into the future".

Operating experience has demonstrated wide variety of assets, which were used for index base while issuing debt securities:

- In 1973 the French government issued Gold bonds ("Giscard") that carried a 7\% nominal coupon rate and a redemption value indexed to the price of one-kilogram bar of gold. As a result of the abolishment of the linkage of currencies to gold in 1978 the bonds increased in value by about $700 \%$ over 10 years.

- In 1980, the Sunshine Mining Company, a large silver mine in the USA, issued US\$25 million worth of silver-indexed bonds. Each US\$1,000 bond was indexed to 50 ounces of silver, had a coupon rate of $8.5 \%$, and a maturity of 15 years. At each bond's maturity, its bearer received the maximum of the face value of US\$1 000 or the market value of 50 ounces of silver. The bonds were redeemable on or after 1995 only if the average silver price for 30 consecutive days was above US $\$ 40$ per ounce.

- In the late 1970s the government of Mexico issued oil-backed bonds (Petrobonds). Each 1,000 peso bond was linked to 1,95354 barrels of oil. The coupon rate was $12,65823 \%$ per annum and matured at the end of 3 years. On the maturity date, the Petrobonds were redeemed at a value equal to the maximum of the face value or the market value of the referenced units of oil.

- In 1984 Inco (one of the world's largest producers of nickel, copper, silver, cobalt, and platinum) raised CAD $\$ 90$ million on the financial market through the issuance of bonds linked to the price of nickel or copper. The bonds, which matured in 1991, paid a coupon rate of $10 \%$ per annum. Holders of the bonds had the option of receiving at the maturity date the face value or the monetary value of a specified amount of nickel or copper. 
- The government of Malaysia accepted a loan from Citibank that was indexed to prices of palm oil. Similarly, Metallgesellschaft used copper-indexed financing to invest in the copper belt of Papua New Guinea (Atta-Mensah, 2004).

- In the mid 1990s, in the aftermath of Hurricane Andrew, several finance and insurance corporations, including AIG, Hannover Re and USAA, issued 'cat bonds' (catastrophe bonds) that enable sponsors to transfer catastrophe risk to capital market investors.

Much greater number of bonds was linked to gross domestic product (or rates of its growth) of the issuer. GDP-linked bonds (also referred to as 'GLB', 'GDP-linked warrants, 'Value-Recovery Rights - VRR', 'State Derivatives') are a debt instrument mirroring the performance of the debtor and his ability of debt repayment.

Advocates of GDP-linked securities describe numerous advantages of international risk sharing. In particular, heavily indebted countries would gain doe to the following:

- Income-indexed bonds allow the indebted government to improve country's prospects for external viability, growth and integration into the world economy, to avoid costly default episodes (the cost of defaulting to be measured by an endowment loss and temporary exclusion from capital markets);

- Being almost always linked with reduction of the total outstanding debt they allow debt-service ratios to fall in times of slow or negative growth, thus reducing the likelihood of immediate defaults;

- GDP indexation of bond repayments could diminish the likelihood of fiscal crises for governments that face a countercyclical borrowing cost, thus limiting the pro-cyclicality of fiscal pressures and facilitating the financing of automatic stabilizers (such as an increase in unemployment benefits and other primary spending during economic downturns). Altogether the likelihood of fiscal crises for governments that face a countercyclical borrowing cost is supposed to be diminishing;

- GLB stabilize government spending also by necessitating smaller interest payments at times of slower growth - providing space for higher spending or lower taxes - and vice versa.

Advantages of GDP-linked securities for the other party - creditors - could include the following: 
- They provide an opportunity for investors to take a position on countries' future growth prospects, i.e. they would offer investors an equity-like exposure to a country;

- They provide a diversification opportunity (combining GDP warrants of different countries with different growth rates in their portfolio);

- Debt-restructuring is accompanied by a rise in the market valuation of creditors' outstanding claims, reflecting the improved prospects for repayment.

In general debt restructuring can be beneficial due to a lower frequency of defaults and financial crises, which often result in costly litigation/renegotiation and sometimes in outright large losses.

Few in number disadvantages of VRR include (i) moral hazard (perverse incentives to misreport growth (or act as incentives to economic underperformance); (ii) problems with pricing these securities and (iii) uncertainty about sufficient liquidity of them (Innovative, 2009, p. 87). Numerous academic papers are concentrated on the development of way to smooth such obstacle.

Abovementioned advantages and other reasons have induced many creditors to use GDP-linked securities while restructuring sovereign debts: during past decades we have witnessed more than a dozen cases of partial sovereign debt forgiveness accompanied by emission of growth-linked securities: in 1989 in Honduras, in 1990 in Costa Rica, Mexico and Venezuela, in 1991 in Nigeria and Uruguay in 1991, in 1993 in Bolivia, in 1994 in Bulgaria, in 1995 in Ecuador, in 1997 in Bosnia, in 1998 in Cote d'Ivoire, in 2005 in Argentina, in 2012 in Greece and in 2015 in Ukraine. In what follows we will briefly examine main terms and conditions of the three most recently issued GDP-linked securities.

Argentina. On December 26, 2001, Argentina defaulted on a total of US\$93 billion of its external debt; the Argentine debt restructuring started on January 14, 2005, and allowed to resume payment on $76 \%$ of the US\$82 billion in bonds.

Initially, Argentina's creditors did not welcome the Argentine Government offer of the GDP warrant arguing that it had little value. But later on creditors and borrowers came to the term. The exchange offered longer term par, quasi-par, and discount bonds - the latter with a much lower nominal value (25-35\% of the original). GDP-linked unit (or warrant) was attached to every restructured Argentinian bond; they were designed to be detached from the underlying bonds 180 days after the issue date, so that they would have their individual trading price after that. So, in essence, the Argentine warrant could be classified as a detachable option. 
The Argentine authorities claim success because of the $50 \%$ to $60 \%$ reduction of debt stock. But, in return, big concessions were made, including indexation to Argentina's GDP growth, which means that the country actually agreed to hand over a share of its growth profits to the creditors.

The notional value of the GDP-linked securities, with a maturity of 30 years, was $\$ 62$ billion. They were issued in the same 3 different currencies - Argentinian Pesos, Euros and US dollars - as the new bonds, and were governed by the same law as the new bonds to which they were initially attached (Warren-Rodriguez and Conceição, 2015).

Payments on warrants according to the agreement had to be made if the 3 conditions were met simultaneously in any particular year between 2006 and 2035:

- Real GDP must be at a higher level than the base GDP.

- Real growth of GDP versus the previous year must be greater than the growth implied by base GDP (from 2015 the base growth rate is flat at 3\%).

When these conditions were met, the Government had to make a payment as follows:

Payment $=((0.05 \mathrm{x}$ excess GDP $) \mathrm{x}$ unit of currency coefficient $) \mathrm{x}$ notional value of GDP-linked securities,

Total cap on payments has been set at $48 \%$ of the value of the securities, thus maximum payable amount on these securities was set at \$US 29.8 billion. The warrants were not callable, that is to say, even if the Argentine Government buys back the debt, it still has to serve the warrant.

At the time of their emission the price of the securities suggested by major investment banks was about $\$ 2$ per $\$ 100$ of notional value. In the following years, the market price of the Argentine GDP-linked securities skyrocketed, with the dollar-denominated warrant reaching a peak of 18.666 cents to a dollar on July 25th 2011. At first market for warrant forwards was not very liquid, with an estimated scale of around US\$ 5 billion, which was relatively small in relation to the total level of warrants issued.

During the first 2 years after the restructuring investors, both foreign and domestic, netted record yields amid renewed growth (8-9\% per year). But since then the rates of growth in Argentina varied greatly - from minus 5,9\% in 2009 to positive $10,25 \%$ in 2010 . In total during 7 years after warrant emission Argentina has paid on them roughly $\$ 6$ billion - around a quarter of a cap.

At present several investment funds that are holding Argentinian GDP-linked bonds are suing the government of Argentina in the Courts of England and the USA, claiming that Argentina had failed to make payments of more than half a billion euro due under the bond. 
The get-away of the Argentinian government for the termination of payment was cessation of publishing as of 2014 the Actual Real GDP in constant 1993 prices (metric agreed by the parties on the controlling documents): in 20114 National Statistics and Censuses Institute (INDEC) decided to replace its calculation of real GDP in constant 1993 prices and that effective 2014 it would base it in constant 2004 prices, so the data needed was no longer available. The claimants argue that Argentina's switch to 2004 prices for the reference year and its decision not to publish GDP data in 1993 prices was improper, irrational, arbitrary and capricious (Klein, 2019).

Appraising Argentinian experience with DP warrants, researchers of the United Nations Department of Economic and Social Affairs Stephany Griffith-Jones and Krishnan Sharma concluded, that "though potentially costly for Argentina, such a scenario could significantly help create a GDP-linked bond market. To the extent that the instrument of GDP-linked bonds is a desirable financial innovation, of benefit to debtors and creditors, Argentina would have done the international community a favour by issuing these warrants and servicing them" [Griffith-Jones and Sharma, 2006].

Greece. In February 2012, Greece issued GDP-linked securities as part of what is considered the biggest sovereign debt restructuring in history. The deal, which was agreed as part of Greece's $€ 130$ billion bailout from the European Union and the IMF, erased about $€ 100$ billion from the country's staggering debt. In the deal, private sector bond-holders approved a loss of $53.5 \%$ of nominal value and over $70 \%$ of the net present value of the Greek bonds they were holding (Bergsten, 2012, p.137).

Participating holders received detachable GDP-linked securities with a notional amount equal to the face amount of new bonds. The securities were supposed to provide an annual payment starting in 2015 until 2042 under the following conditions:

- Nominal GDP equals or exceeds the reference nominal GDP.

- Real GDP growth is positive and in excess of specified target. Based on the set levels of reference GDP levels, the threshold for real GDP growth starts at 2.9\% for 2015, and then gradually falls to $2 \%$ for 2021 and onward.

If real GDP growth for a reference year is lower than the reference real GDP growth rate, then the GDP Percentage Index will also take a value of zero.

Each GDP-linked security was issued with an initial notional value of 100 euros and has an expiration date of 15 October 2042. It uses, as a reference, GDP figures for the Greek economy published by EUROSTAT. Every year holders of GDP-linked securities have to receive a 'Payment Amount' equal to the product of (1) a 'GDP-Indexed Percentage' figure 
obtained for the reference year, multiplied by (2) the 'Notional Amount', provided that actual nominal GDP for the corresponding reference year exceeds the 'reference nominal GDP' figure established for that year (Warren-Rodriguez and Conceição, 2015). In other words:

Payment $=(1.5 \times($ real GDP growth rate - reference real GDP growth rate $)) \mathrm{x}$ notional value of the GDP-linked securities

Each annual payment could not exceed $1 \%$ of the notional value of the bonds. As in the case of Argentina, payment in a given year will not be made until the following year.

Trading of Greece VRR started soon after their emission, with these securities trading as high as 89.2 cents per 100 euros, but afterwards their price had dropped.

Ukraine. Background to debt restructuring. By the time of the presentation of Ukraine's Exchange Offer Memorandum on 22 September, 2015, Ukraine's GDP decreased by an estimated $6.8 \%$ in 2014 and by $14.7 \%$ in the second quarter of 2015 , compared to the corresponding period in 2014. IMF projections expected a 9.0\% rate of decline of GDP for the full year 2015. Economic contraction has been accompanied by a decline in foreign exchange reserves and a sharp depreciation of the hryvnia (from UAH 7,993 in 2013 to UAH 21.85 in September 2015), so compounding the difficulty Ukraine has in meeting its obligations under primarily U.S. dollar-denominated external debt.

Situation was aggravated by annexation of Crimea by Russia in March 2014 and the temporary loss of effective government control over certain areas of eastern Ukraine due to continuing terrorist operations by Russian-backed separatist militias supported by Russian armed forces. As a result, the Ukrainian economy has been deprived of significant sources of productive economic capacity and tax revenue at a time when it had to increase expenditure to cater for, among other things, the needs of large numbers of internally displaced persons and national defense against continuing Russian-sponsored military aggression on Ukrainian territory (Exchange offer, 2015).

Main opponent in restructuring negotiations was American holding company Franklin Templeton, that was holding at that time around $40 \%$ of Ukraine's outstanding bonds. Such “concentration of power", in Reuters analysts' opinion, allowed fund manager Michael Hasenstab to block the restructuring until the Fund got terms that satisfied it (Rao, 2017).

Having no other choice Ukraine agreed to exchange 11 series of Eurobonds issued by Ukraine (due to mature between 2015 and 2023) and 3 series of Eurobonds issued by the State Enterprise for the Financing of Infrastructural Projects (FininPro Bonds, due to mature in 2017 and 2018) for new bonds. In exchange for each $\$ 1,000$ or EUR 1,000 of principal of Designated Securities and Accrued Interest thereon creditors received 9 equal series of New 
Notes in a principal amount equal to the sum of $\$ 800$ (or EUR 800) plus Accrued Interest and GDP-linked Securities in a Notional Amount of U.S.\$200 (or EUR 200). New sovereign notes were carrying a coupon of 7.75\% (increase from 7,22\%) and had to mature between 2019 and 2027. Maximum Notional Amount of the GDP-linked Securities to be issued in connection with the Invitation was approximately $\$ 3607000$ 000. De facto issue size was \$3,214bn with 2916421 notes outstanding.

The warrants have a put option if Ukraine fails to meet certain conditions, including non-payment or moratorium on debt. This would allow holders to ask Ukraine to repurchase the securities at their notional price. The put option expired in December 2018. 2-year gap between the payment year and baseline year was arranged. Trustee for GDP-linked securities is BNY Mellon Corporate Trustee Services Limited.

Through the GDP-linked warrants creditors are entitled to annual payments (from 2021 to 2040) depending on Ukraine's growth.

Payments in 2021 - 2025 (capped at 1\% of GDP) are triggered if:

- Ukraine's GDP rises to or above minimal nominal GDP threshold of US\$125.4bn in any given reference year;

- Real GDP growth exceeds 3\%: payment will be 15\% of the real GDP growth exceeding $3 \%$.

Payments in 2026 - 2040 will be triggered if:

- Ukraine's GDP rises to or above minimal nominal GDP threshold of US\$125.4bn in any given reference year;

- Real GDP growth exceeds 3\% - payment will be $15 \%$ of the real GDP growth exceeding $3 \%$.

- Real GDP growth exceeds $4 \%$ - payment will be $40 \%$ of the growth beyond $4 \%$.

As of December 2019 (latest available data) Ukraine's GDP growth rate was 4,1\%, and GDP in 2019 reached \$150,4 billion.

Calculations presented by Investment Capital Ukraine LLC, show, that possible total amount of payments on warrants (with maximum notional value - \$3,6 billion) in scenario of stable growth of $4 \%$ will be $\$ 5,34$ billion; in case of $5 \%$ growth $-\$ 23,27$ billion, $6 \%-\$ 46,42$ billion and 7\% - \$76,78 billion (Kotovych, 2015). Speaking of which, in 2019 Prime Minister Oleksiy Honcharuk promised GDP growth of $40 \%$ over the course of Zelenskyy's term, equivalent to about $7 \%$ a year. 
Similar calculations, provided by other analysts, caused detachable Ukrainian warrants to soar in price: GDP-linked securities, that had been traded in the highs 40s on issuance, went sub-30 for much of 2016, but have since been steadily recovering, hitting before Covid-19 pandemic par on January 14, 2020 (Ukraine's GDP, 2020).

All GDP-indexed sovereign debt securities, analyzed in this paper, share common features: all of them include a threshold level of the chosen indexation variable above which payments to creditors are triggered; the magnitude of the payments monotonically increases as the chosen indexation variable increases.

But, however, comparative analysis of the terms and conditions of GDP-linked securities issuance by three countries qualify for following conclusion: Ukraine's debt restructuring, termed as 'quietly revolutionary' (Park and Samples, 2015) stands in contrast to Greece's and Argentina's deals.

First of all Ukrainian deal demonstrates that creditors have drawn the lessons from the previous issuances, which were hampered by absence of specific creditor protection mechanisms in them. That is why Ukrainian debt restructuring deal included:

- Put option for certain covenant breaches, providing creditors with the possibility of requiring Ukraine to repurchase the GDP-linked securities at a price equal to their notional amount. Simply put, it enables creditors to be made whole in relation to the haircut.

- Cross-default provisions from the GDP-linked warrants into the newly issued notes stating that breach of certain covenants will trigger cross-defaults into New notes and allow them to be accelerated; thus the failure of the issuer to make any required payment on the GDP-linked Securities on or within 10 days after the relevant Payment Date has to be interpreted as an Events of Default. This means that GDP-linked notes will be ranked pari passu relative to other bonds.

- Covenant Protections designed to insure holders against GDP manipulation, dilution and subsequent invalidity, as well as arbitration for payment disputes.

The latter clause was raised by data manipulation, which has already become judicial matter (see above) in the course of Argentinian VRR servicing, thus attesting to moral hazard problems, faced by the borrowers and frequently mentioned by experts (Krugman, 1988).

In order to mitigate risk of potential misreporting creditors and Ukraine agreed to use data on rate of GDP growth and economic output based on IMF's World Economic Outlook (except for the exchange rate, which is based on NBU data). 
Another point of agreement - postponement of payment for 2 years - considered as advantage for Ukraine, actually can appear to be detrimental: high payments driven by good GDP data in 2019 have to be released in 2021 - after Covid 19 pandemic and yet unknown economic downfall caused by it.

All the abovementioned modifications of Ukrainian GDP-linked warrants can be justified by the negative experience of the creditors of Argentina and Greece. But the next ones should be expressly interpreted as unambiguously adverse for Ukraine (compared to the terms and conditions of previous debt restructuring deals).

To begin with, the haircut for Ukraine was 2-3 times lower, than for other countries: while Argentina received $67 \%$ haircut and Greece $-53,5 \%$, Ukraine got only $20 \%$. And this is even without metering the rise in the cost of servicing of New Notes compared to the restructured ones: from $7,22 \%$ to $7.75 \%$.

Next serious deterioration of terms and conditions: while Greek securities have an annual payment cap of $1 \%$ of the notional amount, and the Argentine warrants have a total payment cap, Ukrainian payments are not limited by the notional amount of the warrants; they have no cap at all for the last 15 years (starting from 2026). Due to this clause Ukrainian GDP-linked warrants, being a very attractive investment for foreign bond-holders, can become a large burden for the government.

Another disfavor for Ukraine is connected with extremely low threshold, giving the kick for GDP-indexed payments - \$125 billion. During preceding the deal seven years GDP of Ukraine was below this threshold only once - in 2009 (\$117,08 billion), while in 2008 it exceeded $\$ 181$ billion, and in 2013 - $\$ 175$ billion. Since the beginning of the millennium Ukraine has achieved annual growth of at least $6 \%$ five times. With a sharp decline in GDP in 2015, Ukraine was prone to see a rebound of growth, which actually took place very soon, thus making warrant payments almost inevitable.

Absence of call option and existence of put option accompanied by cross-default clauses greatly aggravate chances of Ukraine at its GDP-linked notes retirement.

Preliminary conclusion: trend of deterioration of terms and condition for the issuers of GDP-linked notes is evident. Specific terms and condition of Ukrainian VRR do not qualify to interpret this deal as debt 'write-off'.

Three years after Ukraine's issuance of GDP-linked notes twenty co-authors and three editors of the composite book 'Sovereign GDP-Linked Bonds: Rationale and Design' declared their support for VRR and advocated the idea of their effectuality - all of them 
representing interests of creditors and 'a large institutional investor group for which GDP-linked debt is a natural hedge for their risk exposure' (Sovereign GDP, 2017).

Summarizing common approach of authors, Robert Shiller wrote: "The GDP-linked debt has to be issued into a world with existing outstanding nominal and inflation-indexed debt, with laws regulating the debt, such as national debt limits, and with public expectations and rules of thumb regarding the concept of debt, and even public hopes that the debt live up to religious principles, such as the Islamic Shari'ah compliant sukuk... The time has come for sovereign GDP-linked bonds. With this volume they are ready to go" [Sovereign GDP, 2018, pp.7-8].

Final conclusion: Traced in this paper trends in the design of GDP-linked notes clearly demonstrate toughening of the terms and conditions of VRR emission by sovereign debtors - up to a point where alleged 'haircut' may prove to be substantial debt growth. It is about time to borrowers to have the say and jointly elaborate their concept of moral hazard in transactions with VRR - risk that both parties have not entered into a contact in good faith.

\section{References}

Annual Report to the President and to the Congress for Fiscal Year 1986. By National Advisory Council on International Monetary and Financial Policies (U.S.) Volume 1987. Retrieved from https://books.google.com.ua/books?id=DL3ey_ifZyIC\&printsec=frontcover\# $\mathrm{v}=$ onepage $\& \mathrm{q} \& \mathrm{f}=\mathrm{false}$

Atta-Mensah, Joseph. Commodity-Linked Bonds: A Potential Means for Less-Developed Countries to Raise Foreign Capital. Bank of Canada Working Paper 2004-20 June 2004. Retrieved from https://econpapers.repec.org/paper/bcabocawp/04-20.htm

Bergsten, Fred. Global Economics in Extraordinary Times: Essays in Honor of John Williamson. Peterson Institute, Mar 15, 2012

Borensztein, Eduardo; Mauro, Paolo. Reviving the Case for GDP-Indexed Bonds. September 1, 2002. Retrieved from https://www.imf.org/en/Publications/IMF-PolicyDiscussion-Papers/Issues/2016/12/30/Reviving-the-Case-for-GDP-Indexed-Bonds-16054

EXCHANGE OFFER MEMORANDUM DATED 23 SEPTEMBER 2015. Invitation by. Ukraine. Retrieved from fs.ux.com.ua > memorandum

Froot K.A., Scharfstein D.S., and Stein J.C. LDC debt: forgiveness, indexation, and investment incentives. NBER Working Paper No. 2541. Issued in March 1988. Retrieved from https://www.nber.org/papers/w2541 https://doi.org/10.3386/w2541 
Griffith-Jones, Stephany and Sharma, Krishnan GDP-Indexed Bonds: Making It Happen DESA Working Paper No. 21. ST/ESA/2006/DWP/21 April 2006. Retrieved from https://digitallibrary.un.org/record/573925? $1 \mathrm{n}=\mathrm{en}$

Hatgioannides, John, Karanassou, Marika. Warrant Economics, Call-Put Policy Options and the Fallacies of Economic Theory Discussion Paper No. 6251. December 2011. IZA DP No. 6251. Retrieved from https://www.iza.org/publications/dp/6251/warranteconomics-call-put-policy-options-and-the-fallacies-of-economic-theory

Innovative Financing for Development. Edited by Suhas Ketkar and Dilip Ratha. World Bank Publications, Washington, D.C. 2009.

Klein, Michael. Cayman investment funds sue Argentina over bond payout. Cayman compass, August 21, 2019. Retrieved from Cayman investment funds sue Argentina over bond payout - Cayman Compass

Kotovych, Taras. Bond Market Insight. Debt restructuring: Ukrainian version. ICU, December 8, 2015 Retrieved from www.icu.ua > download > ICUDebtInsight-20150710

Krugman, Paul R. "Financing vs. Forgiving a Debt Overhang." Journal of Development Economics 29 (November) 1988. 253-68. Retrieved from https://www.nber.org/papers/w2486 https://doi.org/10.1016/0304-3878(88)90044-2

Park, Stephen and Samples, Tim. Ukraine's quietly revolutionary debt restructuring Financial Times. September 172015 Retrieved from: beyondbrics

Rao, Sujata. Ukraine's growth-linked bonds - when recovery becomes painful. Business News September 15, 2017. Retrieved from https://www.reuters.com/article/ukukraine-bonds-gdp-analysis/ukraines-growth-linked-bonds-when-recovery-becomes-painfulidUKKCN1BQ1UY

Sachs, Jeffrey D. "Conditionality, Debt Relief, and the Developing Country Debt Crisis," NBER Chapters, in: Developing Country Debt and Economic Performance, Volume 1. 1989. Retrieved from https://ideas.repec.org/b/nbr/nberbk/sach89-1.html https://doi.org/10.3386/w2644

Sovereign GDP-Linked Bonds: Rationale and Design. Edited by James Benford, Jonathan Ostry and Robert Shiller. CEPR Press, London. 2018

Ukraine: Gross domestic product (GDP) from 1994 to 2024. Retrieved from https://www.statista.com/statistics/296140/ukraine-gross-domestic-product/

Ukraine's GDP warrants hit par as the country's economic future brightens. By bne IntelliNews. January 14, 2020. https://www.intellinews.com/ukraine-s-gdp-warrants-hit-paras-the-country-s-economic-future-brightens-174552/ 
Warren-Rodriguez, Alex and Conceição, Pedro. Risk-informed finance for development. Discussion paper. UNDP. July 2015. Retrieved from https://www.undp.org/content/undp/en/home/librarypage/poverty-reduction/discussion-paper-risk-informed-finance-for-development.html

Williamson, John. Growth-Linked Securities. Palgrave Macmillan. 2017 https://doi.org/10.1007/978-3-319-68333-1 